Journal of Social Sciences 6 (3): 350-355, 2010

ISSN 1549-3652

(C) 2010 Science Publications

\title{
The Attitude, Belief, Support and Knowledge Level of the Youth and their Acceptance towards Agriculture Contract Farming
}

\author{
Jegak Uli, Jeffrey Lawrence D’Silva, \\ Hayrol Azril Mohamed Shaffril and Bahaman Abu Samah \\ Laboratory of Rural Advancement and Agriculture Extension, \\ Institute for Social Science Studies, University Putra Malaysia, Malaysia
}

\begin{abstract}
Problem statement: Agriculture sector in Malaysia has been intensified through the Eight and Ninth Malaysian Plan. In order to further develop this sector, contract farming activities such as leech rearing, worm rearing, herbs and mushroom have been introduced to the community. But do the communities especially the youth have a positive acceptance towards this activity? Approach: This was a quantitative study. The respondents were among two agriculture learning institutions in Malaysia. From a simple random sampling, a total of 194 respondents were selected. The data collection took two months to be completed. Results: From the multiple linear regression employed, it can be concluded that attitude, belief and knowledge are the significant contributor for acceptance towards contract farming. Conclusion/Recommendation: It is recommended that more studies can be conducted to inspect the complexities related with youths participation in contract farming and special attention should be highlighted to identify what universities can do in strategizing specific agricultural courses that would motivate youth to possess a better acceptance towards contract farming.
\end{abstract}

Key words: Acceptance, youth, contract farming

\section{INTRODUCTION}

The agriculture sector in Malaysia has recorded an encouraging growth during the Eight Malaysian Plan. During this period, the export of agriculture productivity has expanded significantly due to a better price of export volume on agriculture industrial commodities. This sector has persistently provided the raw materials demanded by domestic agro-based industry and not to forget to fulfill the nations food demand. The government's effort to develop this sector has never stopped. In the Ninth Malaysian period, this sector will be intensified as the third income generator for the country. The focus will be on new agriculture which will emphasize more on large-scale commercial farming, use of modern technology, producing high quality and value-added products, unleash the advantage of biotechnology on agriculture, enhance convergence with Information and Communications Technology (ICT) and enhance the involvement of entrepreneurial farmers and skilled workforce. Besides, the roles of agricultural agencies will be intensified to strengthen the service delivery and efficiency.

One of the agriculture branches that has the potential to attract the interests of policy makers, development planners, extension agents and researchers is contract farming. The rise of contract farming activities such as leech rearing, worm rearing, bird nest, herbs and others manage to attract the interest from the public and offer a huge potential to those who are interested to run it. Da Silva (2005) claimed that the need of contract farming has alerted a lot of policy makers, this is not surprising due to changes and trends that influence agro-systems worldwide. The consumption habits of Malaysians has been affected by the rise of fast food outlets either local or international, the emergence of giant hypermarkets such as TESCO, GIANT and CAREFOUR and wider opportunity for international trade in fresh and processed products has demanded a large scale productivity in which contract farming are able to cope with.

Research completed by Md Salleh and Hayrol Azril (2009) and Ezhar et al. (2007) proved that the average age of farmers in Malaysia is exceeding 46 years old while Zaleha (2007) in her study found that majority of farmers were 55 years and above and only less than $26 \%$ of farmers were among those whose age ranged between 18-40 years. All of these bring us to one conclusion; Malaysia need a backup agriculture community. Some initiatives must be taken to attract the youth interest towards agriculture.

Corresponding Author: Jegak Uli, Laboratory of Rural Advancement and Agriculture Extension, Institute for Social Science Studies, University Putra Malaysia, Malaysia 
Without doubt, agriculture can be a way to reduce unemployment problem. Referring to Norsida (2007), youth in Malaysia have a negative acceptance towards agriculture, but stressed that youth still believed that agriculture can generate more money for them if it is accompanied with hard work and good efforts. However, Gidarakou (1999) has an opposite view from Norsida (2007) where she said that youth especially, the female, have negative acceptance towards agriculture activities including contract farming. Gidarakou (1999) has stressed that among the causes why youth have negative acceptance towards agriculture activities are the agricultural sector are perceived as low income occupations and acceptable as an answer to the employment problem only until such time as a better solution can be found. New trends and ways to operate the agriculture activities are needed in order to drive the interest of youth and increase their involvement. Contract farming without doubt have the ability to attract more youth to participate in agriculture activities. Contract farming offers lots of advantages, one of it is consistent supply to the markets. Opportunities for contract farming are huge especially in the field of medicine, health and raw meat products.

Objectives of study: The main purpose of this study is to gain an improved understanding of the factors that help to explain the variation of acceptance towards contract farming among youth. The objectives of the study are to:

- Determine the level of acceptance towards contract farming and to assess their attitude, belief, support and knowledge level

- Assess the proposed four-factor regression model to explain the variation of acceptance towards contract farming among youth

Factors affecting youths acceptance to contract farming: The existing literatures found out there, prove that there are abundance of factors that can be related with acceptance of youth towards contract farming. One of its is the attitude, usually positive attitude will produce a better acceptance and negative attitude will results in lower acceptance. Studies completed by Gidarakou (1999) and Osborne and Dyer (2000) claimed that majority of youth posses a negative attitude towards agriculture activities. Kumar (2007) brings a different view compared to what have been clarified by Gidarakou (1999) where he stressed that the potential that contract farming has got to offer enhance the youth's acceptance of contract farming. Through his research, it can be noted that lately more farmers opted for contract farming due to positive attitude as a result of price protection on their crops. The study done by Kumar (2007) is supported by the study done by Mann and Kogl (2003), where they claimed that bigger profits produced through contract farming can be a major attraction to capture the interest of youth and this without doubt can initiate more positive attitude among youth towards this agriculture activity.

Knowledge can be an important impetus to influence contract farming acceptance among youth. According to Shaban et al. (2006) acceptance can be influenced by the exposure to the pertinent knowledge. Adding to this, James (2004) said people refuse to accept what agriculture can offer including contract farming because of their lack of knowledge. Frick et al. (1995) claimed that acceptance towards agricultural can be further developed if the literacy knowledge level among the community can be enhanced. Knowledge is the key in influencing perception and this trend is set to intensify. The most important element to be practiced for the benefit of this new industry is to practice what have been disseminated. When this happens, it increases the possibility of having more positive acceptance towards contract farming.

Support without doubt is important to ensure the success of contract farming. A study conducted by Guo et al. (2005) clarified that government support, contractor characteristics and product or enterprise type are the major factors that influence people acceptance towards contract farming. Government support is significant in motivating and encouraging youth to accept contract farming. Based on a study completed by Wheeler (2008), it can be concluded that those who are interested in contract farming need more assistance to do so especially on information seeking, specialist extension support, farm demonstration and policy support. Doubtlessly belief is an important determinant for strengthening acceptance towards contract farming (Adrian et al., 2005). When people believe contract farming is beneficial to them, usually it will increase their acceptance towards contract farming.

\section{MATERIALS AND METHODS}

A total of 194 students from two agriculture learning institutions were selected as the respondents for this study. A pre-tested and developed questionnaire was used to gain the data needed. Results of the pre test produced a Cronbach Alpha between 0.85-0.92 on the different constructs. These high values show that the items used to measure the various construct indicate a good level in term of reliability. Self-administered method was used to collect the data required. Selected 
descriptive statistics such as frequency, percentage, mean and standard deviation were used to analyze the first objective of the study, in addition, Multiple Linear Regression was employed to assess the proposed fourfactor regression model to explain the variation of acceptance towards contract farming among youth. The dependent variable for this study is acceptance towards contract farming while there are four independent variables of this study namely attitude, belief, support and knowledge. This study hypothesizes that a person's attitude, knowledge, belief and support are positively related to acceptance to acceptance towards contract farming. A positive relationship suggests that the acceptance towards contract farming is more apt to increase when the attitude, knowledge, belief and support for contract farming increase.

\section{RESULTS}

Table 1 indicates to us the socio-demographic data of the respondents studied. A large majority of the respondents are females $(62.4 \%)$ and do not have agriculture background $(75.8 \%)$. Slightly more than two fifth $(42.3 \%)$ of the respondents are between 20-21 years old. There are quite balance number of respondents who are currently taking degree course $(48.5 \%)$ and diploma course $(51.5 \%)$. Majority of the respondents $(30.9 \%)$ spent between more than RM400 a month compared to only $11.3 \%$ of respondents who only spend less than RM200 a month. Nearly two third of the respondents $(62.9 \%)$ stayed in urban areas.

Table 2 provides the actual scores of the overall level of acceptance of the respondents towards contract farming. A mean of 7.27 indicates in general, the level of acceptance towards contract farming among the youth was high. Based on the scoring procedure used, nearly three fourth $(70.6 \%)$ of the respondents rated highly their acceptance towards contract farming. Slightly more than one-fourth (29.4\%) of the respondents rated moderately their acceptance towards contract farming. The data presented in Table 2 display an interesting result where none of the respondents rated their acceptance towards contract farming in the low category.

Table 1: Socio demographic of respondents

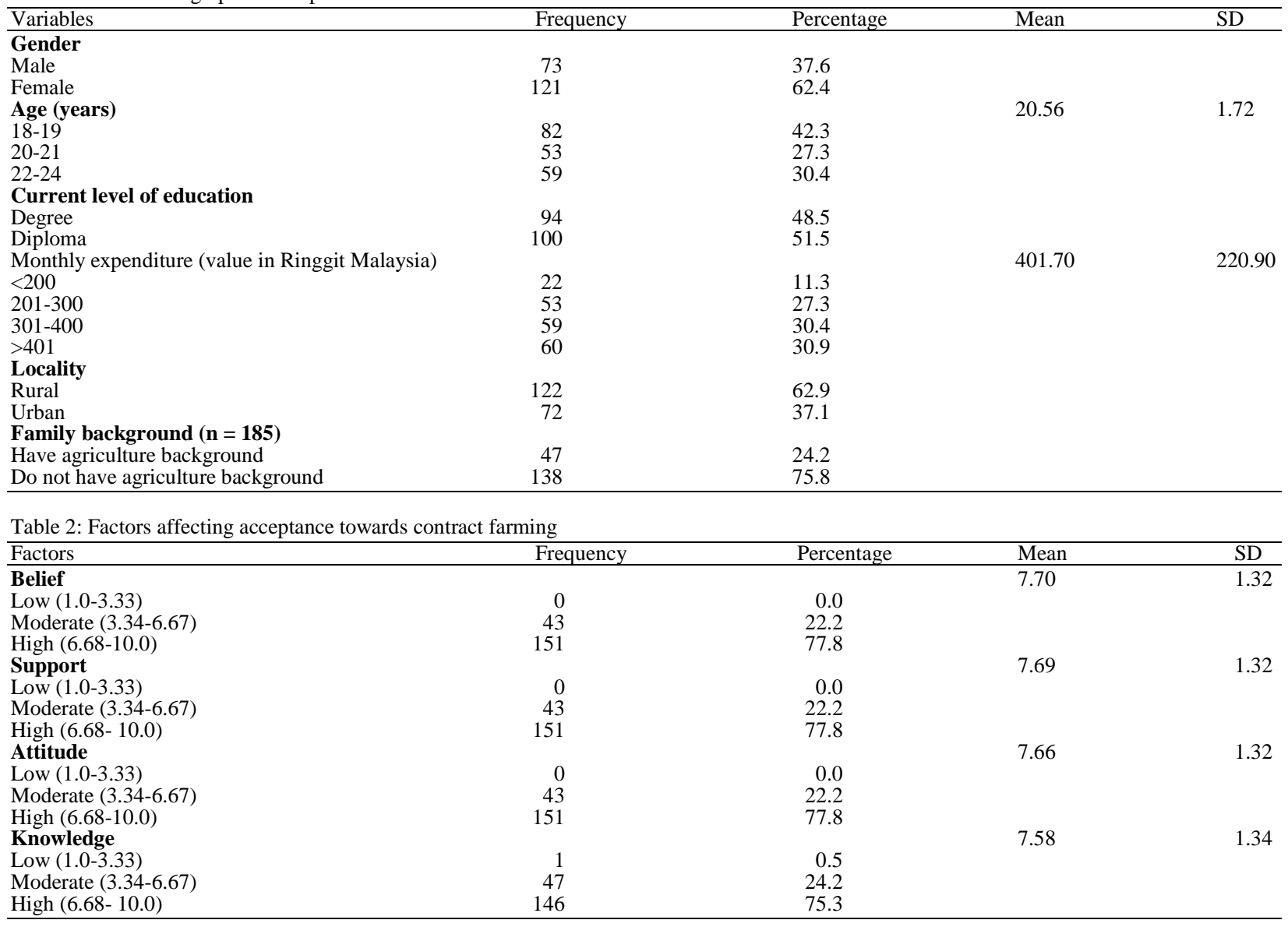


J. Social Sci., 6 (3): 350-355, 2010

Table 3: Estimates of coefficients for the model

\begin{tabular}{llllll}
\hline Factors & $\mathrm{B}$ (unstandardized coefficients) & Std. error & Beta (standardized coefficients) & $\mathrm{t}$ & $\mathrm{p}$-value \\
\hline Constant & 1.229 & 0.431 & & 2.856 & 0.005 \\
Attitude $\left(\mathrm{X}_{1}\right)$ & 0.445 & 0.058 & 0.503 & 7.716 & 0.0001 \\
Knowledge $\left(\mathrm{X}_{2}\right)$ & 0.157 & 0.060 & 0.180 & 2.617 & 0.010 \\
Belief $\left(\mathrm{X}_{3}\right)$ & 0.104 & 0.051 & 0.118 & 2.028 & 0.044 \\
Support $\left(\mathrm{X}_{4}\right)$ & 0.231 & 0.172 & 0.082 & 1.338 & 0.182 \\
\hline
\end{tabular}

Notes: $\mathrm{R}=0.75 ; \mathrm{R}^{2}=0.57$; Adj. $\mathrm{R}^{2}=0.56, \mathrm{~F}(4,194)=62.25$

Level of belief, support, attitude and knowledge: Table 2 also shows the actual scores of the level of belief, support, knowledge and attitude of respondents towards contract farming. The score ranged from 1-10. Results presented indicate that belief recorded the highest mean score $(\mathrm{M}=7.70, \mathrm{SD}=1.32)$ followed by support $(\mathrm{M}=7.69, \mathrm{SD}=1.32)$. The lowest mean score was recorded by knowledge $(\mathrm{M}=7.58, \mathrm{SD}=1.34)$. All the scores were above 7.0 suggesting that the overall level for each variable was high. These findings suggest that the youth are quite positive and quite knowledgeable about contract farming and at the same time they show strong support and have good belief about it.

Factors explaining the variation of acceptance towards contract farming: A four factor linear regression model was proposed to explain the variation acceptance towards contract farming among youth. The four-factor variables multiple linear regression model were attitude $\left(\mathrm{X}_{1}\right)$, support $\left(\mathrm{X}_{2}\right)$, knowledge $\left(\mathrm{X}_{3}\right)$ and belief $\left(\mathrm{X}_{4}\right)$. Therefore, the equation of the proposed multiple linear regression model is as follows:

$Y($ Acceptance $)=b_{0}+b_{1}\left(X_{1}\right)+b_{2}\left(X_{2}\right)+b_{3}\left(X_{3}\right)+b_{4}\left(X_{4}\right)+e$

Where:

$\mathrm{Y}=$ Acceptance

$\mathrm{b}_{0}=$ Constant (intercept)

$\mathrm{b}_{1-5}=$ Estimates (regression coefficients)

$\mathrm{X}_{1}=$ Attitude

$\mathrm{X}_{2}=$ Knowledge

$\mathrm{X}_{3}=$ Belief

$\mathrm{X}_{4}=$ Support and

$\mathrm{e}=$ Error

To determine to what extent the research data fit the proposed multiple linear regression model, enter regression method was used. Based on the enter method, only three of the four predictor variables were significant in explaining acceptance $F(4,194)=62.25$, $\mathrm{p}=0.0001$. The three predictor variables were: attitude $(\mathrm{t}=7.72, \mathrm{p}=0.000)$, knowledge $(\mathrm{t}=2.62, \mathrm{p}=0.01)$ and belief $(\mathrm{t}=2.03, \mathrm{p}=0.044)$. The factors of support $\left(\mathrm{X}_{4}\right)$ was not significant $(t=134, p=0.18)$. This suggests that four-predictor MLR model was only partially supported by the research data.
As depicted in the coefficients table (Table 3), the estimates ( $B$ weights) of the model coefficients for $b_{0}$ is $1.23, b_{1}$ is $0.45\left(\mathrm{X}_{1}\right), \mathrm{b}_{2}$ is $0.14, \mathrm{~b}_{3}$ is 0.10 and $\mathrm{b}_{4}$ was 0.23 . According to this $\mathrm{B}$ weights, the estimated regression equation model as follows:

$\begin{aligned} \mathrm{Y}(\text { Acceptance })= & 1.23+0.45\left(\mathrm{X}_{1}\right)+0.15\left(\mathrm{X}_{2}\right)+0.10 \\ & \left(\mathrm{X}_{3}\right)+0.23\left(\mathrm{X}_{4}\right)+\mathrm{e}(2)\end{aligned}$

Where:

$\mathrm{Y}=$ Acceptance

$\mathrm{b}_{0}=$ Constant (intercept)

$\mathrm{b}_{1-5}=$ Estimates (regression coefficients)

$\mathrm{X}_{1}=$ Attitude

$\mathrm{X}_{2}=$ Knowledge

$\mathrm{X}_{3}=$ Belief

$\mathrm{X}_{4}=$ Support

$\mathrm{e}=$ Error

The $\mathrm{R}^{2}$ of 0.57 implies that the four predictor variables explain about $57.0 \%$ of the variance/variation in acceptance toward contract farming. This is quite a good and respectable result. The ANOVA table tests the null hypothesis and the multiple $\mathrm{R}$ in the population equals 0 . The ANOVA table revealed that the Fstatistics $(F(4,194)=62.25)$ is very large and the corresponding p-value is highly significant $(0.0001)$ or lower than the alpha value of 0.05 indicating that the null hypothesis was rejected and thus the multiple $\mathrm{R}$ is not equal to zero and thus confirming that there is linear relationship between the predictor variables and acceptance towards contract farming.

As depicted in Table 3, the largest beta coefficient is 0.50 which is for attitude. This means that this variable makes the strongest unique contribution to explaining the dependent variable (acceptance towards contract farming), when the variance explained by all other predictor variables in the model is controlled for. It suggests that one standard deviation increase in organization climate is followed by 0.503 standard deviation increase in acceptance toward contract farming. The Beta value for knowledge is 0.18 , belief was 0.12 , while standardize coefficient for support was the smallest (0.08) and indicating that it made the least contribution. 
J. Social Sci., 6 (3): 350-355, 2010

Table 4: Correlation table

\begin{tabular}{llllll}
\hline Pearson correlation & Acceptance & Attitude & Belief & Knowledge & Support \\
\hline Acceptance & 1.000 & 0.717 & 0.492 & 0.605 & 0.502 \\
Attitude & 0.717 & 1.000 & 0.491 & 0.631 & 0.527 \\
Belief & 0.492 & 0.491 & 1.000 & 0.515 & 0.428 \\
Knowledge & 0.605 & 0.631 & 0.515 & 1.000 & 0.583 \\
Support & 0.502 & 0.527 & 0.428 & 0.583 & 1.000 \\
\hline
\end{tabular}

Several methods can be used to check for the presence of multicollinearity of the MLR model. The first one is using the correlation table (Table 4) suggested to check that the correlation between each of the independent variable.

\section{DISCUSSION}

If contract farming is to be an attractive income generating economic activity, the youth must show positive attitude, have great belief, support the concept and at the same time be knowledgeable about it. Without these, their level of acceptance towards contract farming concept will not received its full potential. One important implication of the findings of this study is that in order to increase the acceptance of youth towards contract farming significantly we need to increase the level of attitude, belief, support and their knowledge about the farming concept. These could only be achieved through well-organized workshops, seminars and other forms of effective communication channels to disseminate information on the viability of contract farming as an alternative form of income generating to the youth in the institution of higher learning at the tertiary level. Such programs, if effectively implemented would not only substantially raise the awareness, but could also help to achieve very high level of acceptance among youth. Eventually, this can be one of the ways to attract youth to be part of innovative farming activities and in end it would create more attractive agriculture activities and maintain its sustainability.

\section{CONCLUSION}

The study concludes that the level of acceptance towards contract farming was high among the respondents. The survey revealed their level of belief, support, attitude towards contract farming and their knowledge on contracting farming were also high. These findings suggest that the youth are quite positive and knowledgeable about contract farming. In addition, belief, support and attitude towards contract farming are important factors in explaining variation of acceptance towards contract faming. Thus the four-factor model was partially supported by the research data. The expected positive linear relationship for $\mathrm{X}_{1}$ (attitude) and $\mathrm{Y}$ and $\mathrm{X}_{2}$ (knowledge) and $\mathrm{Y}, \mathrm{X}_{3}$ (belief) and $\mathrm{Y}$ were also supported by research data. However, the relationship between $\mathrm{X}_{4}$ (support) and $\mathrm{Y}$ was not supported. Overall, the model is a very good descriptor of the variation of acceptance towards contract farming and it was found to be stable and reliable model.

\section{REFERENCES}

Adrian, A.M., S.H. Norwood and P.L. Mask, 2005. Producer's perception and attitudes towards precision agriculture technologies. J. Comput. Technol. Agric., 48: 256-271. DOI: 10.1016/j.compag.2005.04.004

Da Silva, C., 2005. The growing role of contract farming in agrifood systems development; drivers, theory and practice, working document, agricultural management. Market. Fin. Service. http://www.fao.org/ag/ags/subjects/en/agmarket/co ntractfarming.html

Ezhar, T., M.S. Rahim, M. Zainal Abidin, H. Mohamed Rezal Y. and Zamre, 2007. Micro Agro-based Entrepreneurs Readiness in Facing Agriculture Challenges. IPSAS Monograph Series Bil. 1/2007, University Putra Malaysia Publisher, Serdang, Malaysia, pp: 7.

Frick, M.J., R.J. Birkenholz, H. Gardrner and K. Machtmes, 1995. Rural and urban inner-city high school student knowledge and perception of agriculture. J. Agric. Educ., 36: 1-9.

Gidarakou, I., 1999. Young women's attitude towards agriculture and women new roles in the Greek countryside: A first approach. J. Rural Stud., 15: 147-158. DOI: 10.1016/S0743-0167(98)00054-0

Guo, H., R.W. Jolly and J. Zhu, 2005. Contract Farming in China: Supply Chain or Ball Chain? Proceeding of the Minnesota International Economic Development Conferences, (MIDC'05), University of Minnesota, US., pp: 29-30.

James, J.S., 2004. Consumer knowledge and acceptance of agricultural biotechnology vary. J. Calif. Agric., 58: 99-105. http://escholarship.org/uc/item/7km20933

Kumar, P., 2007. Resources provision, productivity and contract farming: A case study of Punjab. Proceeding of the ICAR-NCAP and USAID, May 5-6, New Delhi India. 
Mann, S. and H. Kogl, 2003. On the acceptance of animal production in rural communities. J. Land Use Policy, 20: 243-252. DOI: 10.1016/S02648377(03)00025-5

Md Salleh, H. and M.S. Hayrol Azril, 2009. Internet usage among agro-based entreprenuers: Can it affect productivity. J. Agric. Ext. Soc. Sci., 5: 61-66.

Norsida, M., 2007. The Agricultural Community. 50 Years of Malaysian Agriculture. Malaysian Agriculture: Transformational Issues, Challenges and Direction Serdang, Selangor: Penerbit UPM, Serdang, Malaysia, ISBN: 978-967-5026-14-0, pp: $128-144$.

Osborne, E.W. and J.E. Dyer, 2000. Attitudes of illinois agriscience students and their parents towards agriculture and agricultural education program. J. Agric. Educ., 41: 50-59.
Shaban, A., W.A. Doppler and H. Wolff, 2006. Determinants of farmers acceptance of treated wastewater in irrigated agriculture in the Northern Gaza strip. Proceeding of the Conference on International Agriculture Research for Development, Oct. 11-13, Tropentag, Germany, pp: 1-5. http://www.tropentag.de/2006/abstracts/full/254.pdf

Wheeler, S.A., 2008. The barriers to further adoption of organic farming and genetic engineering in Australia: Views of agricultural professionals and their information sources. J. Renew. Agric. Food Syst., 23: 161-170. DOI: 10.1017/S1742170507002128

Zaleha, M.N., 2007. Labor in Agriculture. In: 50 Years of Malaysian Agriculture: Transformational Issues, Challenges and Direction, Fatimah Arshad et al. (Eds.). UPM Publisher, Serdang, Selangor, ISBN: 978-967-5026-14-0, pp: 652-658. 